\title{
Development of the New Method for Oxidized Nickel Ore Processing
}

\author{
Boris Dmitrievich Khalezov, Oleg Vadimovich Zayakin, \\ Alexey Sergeevich Gavrilov, and Vladimir Ivanovich Zhuchkov \\ IMET UB RAS, Ekaterinburg, Russia
}

\section{Abstract}

In modern conditions of sharp fluctuations in nickel prices on world markets, the problem of profitability of processing Russian poor oxidized nickel ores (ONO) has arisen. As an alternative to the previously existing in Russia, a sulphidation-reducing smelting on a matte, a hydro-pyrometallurgical method has been proposed for the preparation of complex nickel-, chromium-, manganese-containing ferroalloys. At the first stage, hydrolytic precipitation (with sodium hydroxide) is considered as a method of processing production solutions from heap leaching of ONO. It is established that

Corresponding Author: Oleg Vadimovich Zayakin zferro@mail.ru

Received: 5 February 2019 Accepted: 6 March 2019 Published: 17 March 2019 Publishing services provided by Knowledge E

(c) Boris Dmitrievich Khalezov et al. This article is distributed under the terms of the Commons Attribution License, which permits unrestricted use and redistribution provided that the original author and source are credited.

Selection and Peer-review under the responsibility of the NIOKR-2018 Conference Committee. at $\mathrm{pH}=5.5, \mathrm{Al}$ is completely removed in the precipitate as hydroxide. After washing from impurities and calcining, a concentrate containing $50 \mathrm{wt}$ \% Al was obtained. At the second stage, at $\mathrm{pH}=9.5$, more than $99 \%$ of nickel and cobalt oxides, as well as $92 \%$ $\mathrm{MnO}$ and $46 \% \mathrm{MgO}$, are precipitated. Obtained after washing and calcination at $700^{\circ} \mathrm{C}$ oxide concentrate contains, by weight. \%: $67 \mathrm{NiO} ; 3 \mathrm{CoO} ; 20 \mathrm{MnO} ; 9 \mathrm{MgO} ; 0,2 \mathrm{~S}$. At the third stage, a pyrometallurgical method for smelting complex ferroalloys of the Fe-Ni-Cr$\mathrm{Mn}$-Si system using refractory ferrosilicochrome as a reducing agent is proposed for the processing of nickel-containing concentrate. The scheme of hydro pyrometallurgical method of ONO processing includes: crushing, heap leaching, hydrolytic precipitation to obtain an aluminum-cobalt and nickel concentrates, silicothermic smelting to obtain complex nickel, chromium, manganese ferroalloys, for smelting of suitable stainless steels.

Keywords: oxidized nickel ores, nickel, cobalt, manganese, leaching, precipitation, roasting, metallothermy

\section{Introduction}

Despite the fact that stainless steels are one of the most promising and mass materials in the world, their production in the Russian Federation is unreasonably low [1]. If in the world by 2070 it is planned to produce 70 million tons of steel per year, then in 
rest of stainless steel needs are closed by imports. Nickel-, chromium and manganesecontaining ferroalloys are widely used for smelting special alloyed steels and alloys, in particular, corrosion-resistant. The main part of costs in the production of stainless steels accounts for nickel and chromium alloys. Under conditions of instability in world prices for alloying components, primarily for nickel, enterprises with their own ore base and production of ferroalloys for steel production, have certain advantages. A unique combination of nearby deposits of oxidized nickel and chrome ores, as well as ferroalloy and steel-making enterprises, determines the expediency of organizing in the Serov city Sverdlovsk region, [2], on the basis of an existing plant producing ferrochrome, ferronickel and stainless steel production.

Russia is among the largest ten world producers of ferrochrome [3], which cannot be said about ferronickel. In our country, for the production of high-quality corrosionresistant steels, electrolytic nickel (containing about $99 \%$ by weight $\mathrm{Ni}$ ) is used predominantly. Its high cost does not contribute to the development of the nickel-containing steels production. The solution to this problem may be the use of relatively cheap nickel ferroalloys (containing $10-40 \% \mathrm{Ni}$ ), the deficit of which is currently felt in Russia. At the same time, the Russian Federation has sufficient reserves of poor oxidized nickel ores (ONO), suitable for the production of this type of alloys. Domestic ONO of silicate type localized mainly in the Urals.

Comparison of Russian ONO with ores that are processed abroad shows that in the latter nickel content is mostly at $1.9-2.5 \%$, while Russian ores are poorer, they contain on average $0.7-1.2 \% \mathrm{Ni}[4,5]$.

Until recently, the Urals ONO were processed according to the technologically outdated and environmentally dangerous processing scheme, the main process of which was sulphidation-reducing smelting to matte. To date, the processing of ONO in the Urals has been discontinued due to unprofitable process.

In modern conditions, four methods for the pyrometallurgical production of ferronickel are industrially used: the blooming process, shaft, blast and electric smelting [6]. Of these pyrometallurgical methods, electric smelting with preliminary calcination of ore in a rotary tube furnace developed by the Norwegian company Elkem has become the most common. Electric melting does not require ore agglomeration. It is suitable for ores with different content of refractory slag-forming components. It has good environmental performance and it is characterized by high extraction of nickel and cobalt and the production of slags containing the minimum amount of these metals, which makes it 
possible to use slags as building materials and to implement almost waste-free technology processing of ONO [7]. At the same time, only poor ferronickel (less than $7 \% \mathrm{Ni}$ ) can be obtained from domestic ONO with a high iron content [8].

In recent decades, autoclave and ammonia carbonate technologies for processing rich ONO have been introduced in the world [9-11]. Some agitation nitro-, hydrochloric and sulfuric acid leaching methods are investigated [12-15]. There is a brief information about the heap processing of ONO $[16,17]$. The production of nickel using special Alyssum murale plants capable of selectively accumulating nickel are also known [18].

These methods allow to process ONO. However, it should be noted that the application of described methods for processing Russian ONO will present certain technological difficulties due to the poor of the ore materials with regard to nickel content 1 wt.\% Or less) and high magnesium content (10-20 wt.\%).

The solution to the profitability issues of processing domestic poor ONO today, is the creation of a new promising technology for their processing. As an alternative to the reduction smelting on matte previously existing in Russia, it is possible to consider a hydro-pyrometallurgical method of obtaining complex ferroalloys of the Fe-Ni-Cr-Mn-Si system.

\section{Results and Discussion}

Samples of iron-magnesia ONO from the Serovskoye deposit were selected as the object of research. The presented ore sample is the most difficult to process by existing industrial methods. The chemical composition of the original ore is presented in Table 1.

TABLE 1: The chemical composition of the oxidized nickel ore, wt. \%.

\begin{tabular}{|c|c|c|c|c|c|c|c|c|}
\hline $\mathbf{N i}$ & $\mathbf{C o}$ & $\mathbf{M g}$ & $\mathbf{C u}$ & $\mathbf{A l}$ & $\mathbf{S i}$ & $\mathbf{F e}$ & $\mathbf{M n}$ & $\mathbf{S}$ \\
\hline 1.19 & 0.039 & 18.9 & 0.012 & 3.05 & 17.39 & 14.83 & 0.57 & 0.13 \\
\hline
\end{tabular}

In the laboratory we got solutes by the percolation leaching of ONO samples in a special installation (Figure 1) containing, g/dm $: 1-2 \mathrm{Ni}, 0.04-0.06 \mathrm{Co}, 1.5-1.8 \mathrm{Al}, 0.6-1.9 \mathrm{Mn}$, 8.9-19.9 Mg, 0.02-0.60 Fe. In the leaching process, a significant amount of manganese, magnesium and aluminum also goes into solute, along with nickel and cobalt. To extract them from the solute, hydrolytic precipitation was used. Precipitation was carried out at room temperature in 2 stages at $\mathrm{pH}=5.5$ and 9.5 , feeding sodium hydroxide to precipitation. 


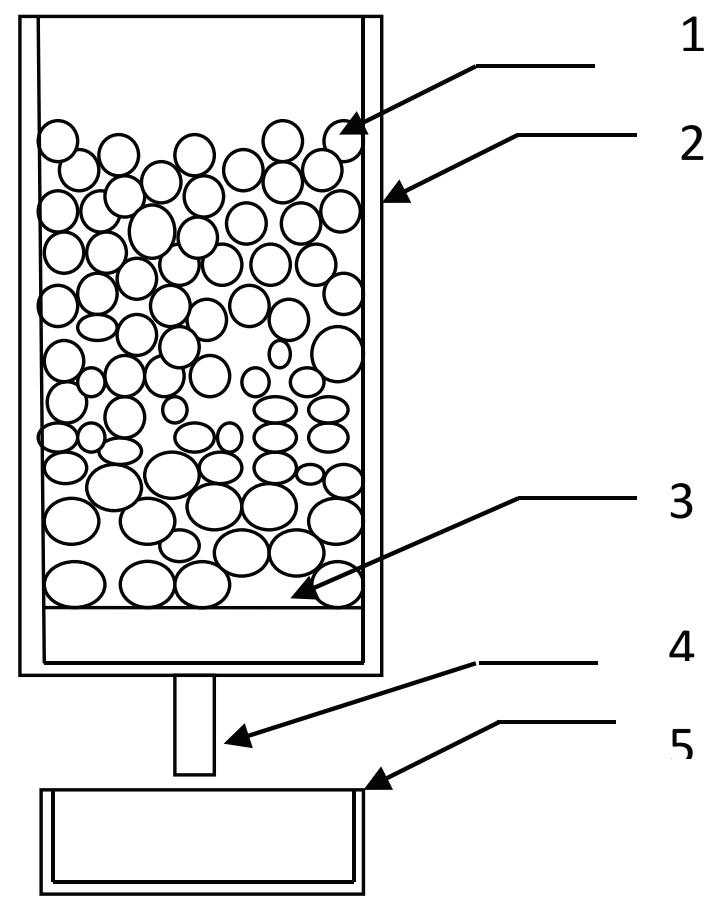

Figure 1: Percolator circuit; 1 - ore; 2 - percolator frame; 3 - false bottom; 4 - exhaust pipe; 5 - container for collecting solutes.

At the first stage was obtained the precipitate at $\mathrm{pH}=5.5$, containing, by weight, wt. \%: 18.8 Al, 1.26 Fe, 1.22 Ni, 0.05 Co, 0.27 Mn, and 1.31 Mg. The precipitate was washed with water to remove metal impurities, contained in the mother liquors. After roasting at a temperature of $700^{\circ} \mathrm{C}$ for 2 hours, was obtained a precipitate, containing $50 \mathrm{wt} . \% \mathrm{Al}$ and about 4 wt.\% impurities.

At the second stage nickel, cobalt and manganese were selectively extracted from the production solutes at $\mathrm{pH}=9.5$. The result is a precipitate containing, in wt.\%: 32.5 Ni, 1.41 Co, 10.2 Mn, 8.1 Mg, 9.65 S, < 0.001 P, < 0.001 As, $0.05 \mathrm{Cu}, 0.66 \mathrm{Zn}$. Figure 2, Tables 2 and 3 show the dependence of nickel and cobalt extraction on the level of acidity (pH). $99 \%$ of nickel and $99.5 \%$ of cobalt are extracted from the solute $(\mathrm{pH}=9.5)$. Along with nickel and cobalt, about $96.5 \%$ of $\mathrm{Mn}$ and $73.3 \%$ of $\mathrm{Mg}$ are also extracted into the concentrate (Tables 2 and 3; Figure 3).

To remove the sulfur contained in the precipitate and part of impurities of other elements, the precipitate was washed with water at $\mathrm{pH}=7$, and then roasted at a temperature of $700^{\circ} \mathrm{C}$. The result was a material of the following composition, wt.\%: $67 \mathrm{NiO} ; 3$ $\mathrm{CoO} ; 20 \mathrm{MnO} ; 9 \mathrm{MgO} ; 0,2 \mathrm{~S}$.

The pyrometallurgical method of smelting complex ferroalloys has been proposed for processing nickel-containing concentrate. As earlier studies have shown [19, 20], 


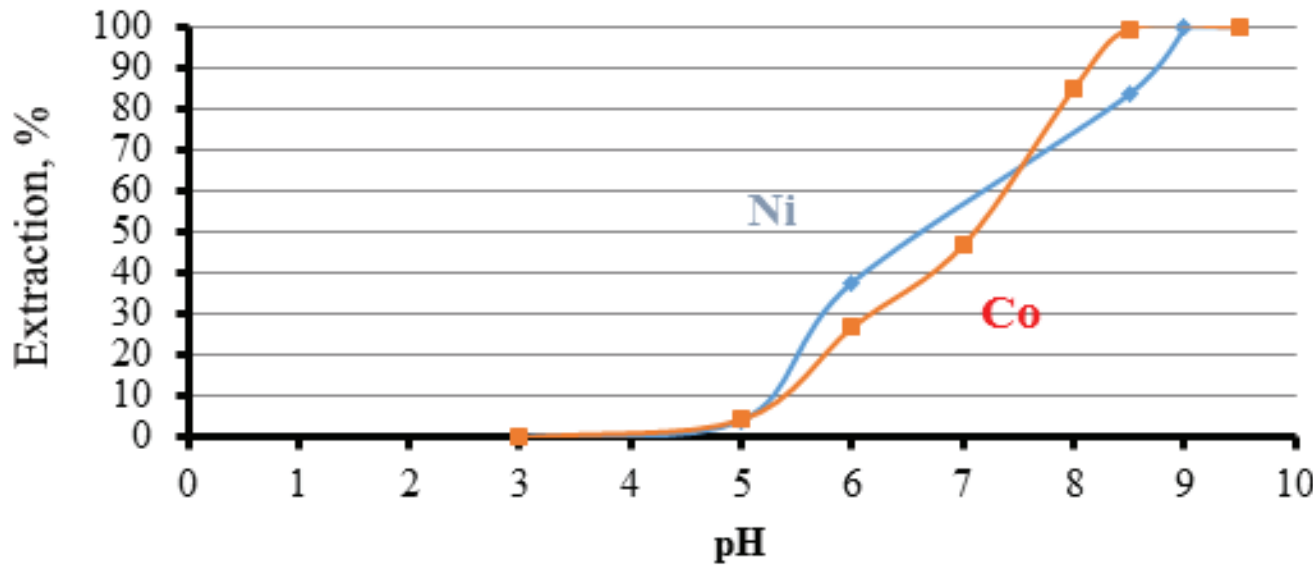

Figure 2: The dependence of the nickel and cobalt extraction degree on $\mathrm{pH}$.

TABLE 2: The dependence of elements content in the solution on $\mathrm{pH}$.

\begin{tabular}{|c|c|c|c|c|c|c|c|}
\hline \multirow[t]{2}{*}{ pH } & \multirow[t]{2}{*}{$\mathbf{V}, \mathbf{s m}^{3}$} & \multicolumn{6}{|c|}{ Content of elements, $\mathbf{g} / \mathrm{dm}^{3}$} \\
\hline & & Al & $\mathrm{Fe}$ & Co & $\mathbf{N i}$ & Mn & Mg \\
\hline 3,5 & 500 & 1,43 & 0,0021 & 0,063 & 2,01 & 1,85 & 15,59 \\
\hline 4 & 502 & 1,430 & 0,0018 & - & - & - & 15,08 \\
\hline 4,5 & 482 & 0,850 & 0,0009 & - & - & - & - \\
\hline 5 & 510 & 0,069 & $1^{*} 10^{-4}$ & 0,059 & 1,830 & 1,67 & - \\
\hline 5,5 & 481 & 0,0056 & $1 * 10^{-4}$ & - & - & - & 13,9 \\
\hline 6 & 451 & $1,7^{*} 10^{-3}$ & - & 0,051 & 1,650 & - & - \\
\hline 6,5 & 420 & $1,7^{*} 10^{-3}$ & - & - & - & - & - \\
\hline 7 & 391 & - & - & 0,043 & - & 1,18 & 12,74 \\
\hline 7,5 & 361 & - & - & - & - & - & 11,46 \\
\hline 8 & 332 & - & - & - & 1,350 & - & - \\
\hline 8,5 & 330 & - & - & 0,014 & 0,500 & 0,84 & 10,77 \\
\hline 9 & 313 & - & - & $4^{*} 10^{-3}$ & $4,5^{*} 10^{-3}$ & 0,49 & - \\
\hline 9,5 & 291 & - & - & - & - & 0,11 & 8,49 \\
\hline 10 & 278 & - & - & - & - & 0,039 & - \\
\hline 10,5 & 339 & - & - & - & - & $1 * 10^{-4}$ & 0,92 \\
\hline 12,5 & 500 & - & - & - & - & - & 0,016 \\
\hline Extra & lution, \% & 99,26 & 99,99 & 99,59 & 99,43 & 99,68 & 99,2 \\
\hline
\end{tabular}

complex ferroalloys have higher production characteristics, compared to standard twocomponent alloys. In metallurgy, metallothermic reduction of metals from oxides using silicon, that is one of the main reducing agents in the production of low carbon ferroalloys (ferromanganese, ferrochrome, ferrovanadium, etc.), has been widely used [21]. We have proposed to use silicon from ferrosilicochrome brand FSC48 (GOST 11861-91) containing, 
TABLE 3: The dependence of the extraction degree of elements in the sediment from $\mathrm{pH}$.
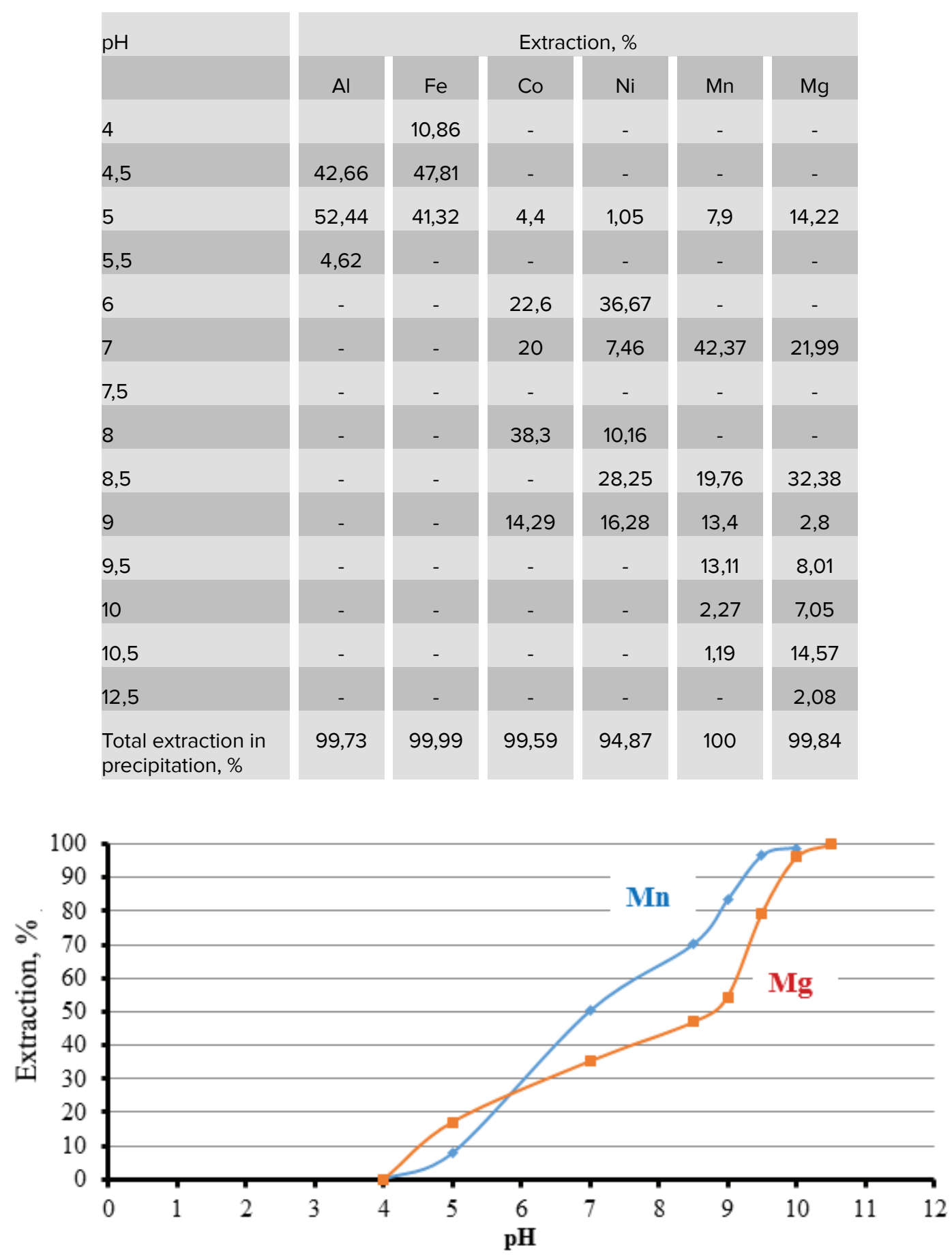

Figure 3: The dependence of manganese and magnesium extraction degree from $\mathrm{pH}$.

by mass, \%: $48 \mathrm{Si} ; 30 \mathrm{Cr}$ and $21 \mathrm{Fe}$, to reduce nickel, cobalt, and manganese from the oxide material obtained by the hydrometallurgical method. The reducing agent was set in the amount of $50 \%$ of the nickel-containing concentrate mass based on the silicon content for the complete reduction of nickel, cobalt and manganese, taking into account the silicon loss and maintaining the residual silicon in the final ferroalloy at the level of 


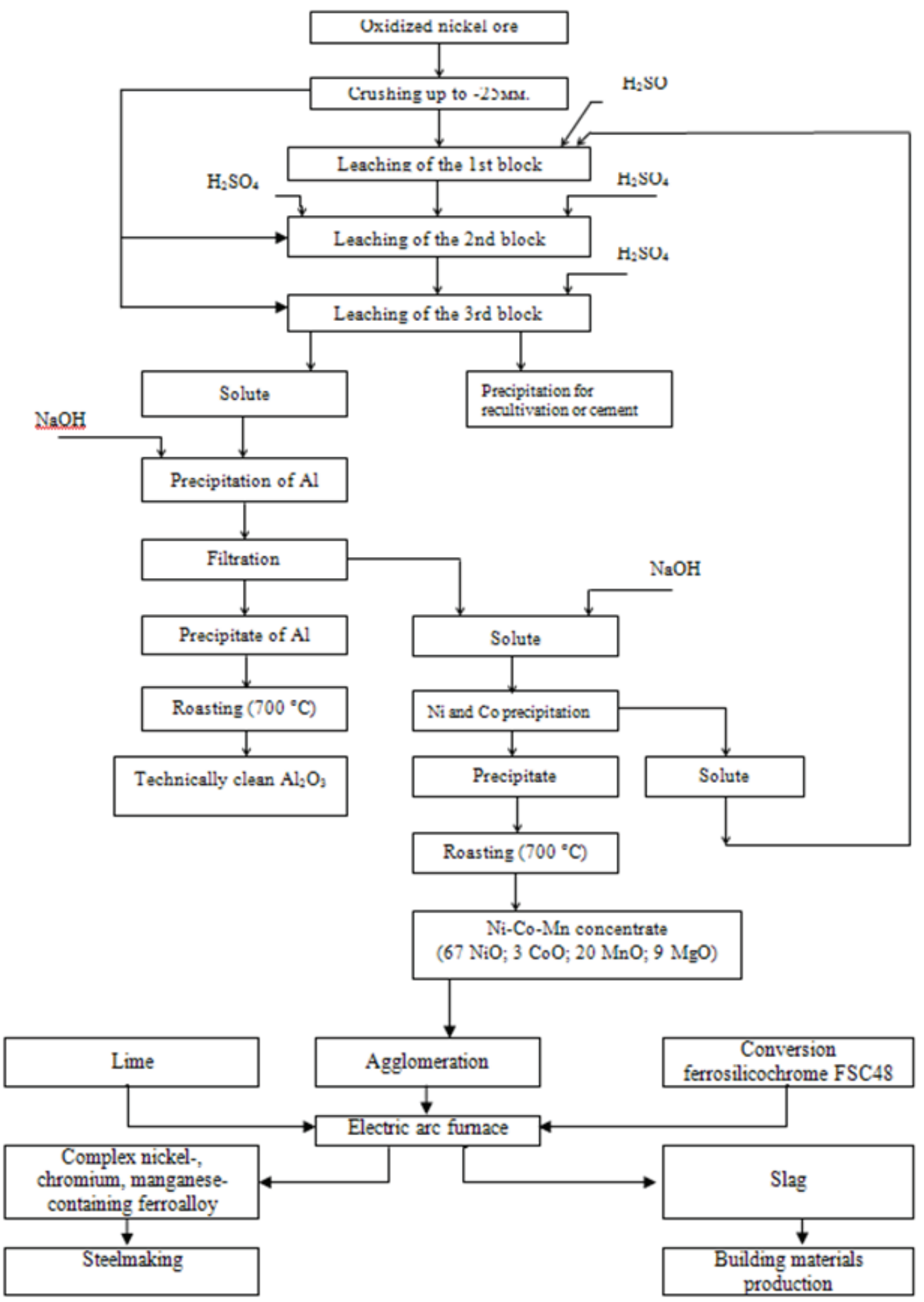

Figure 4: Technological scheme of hydro-pyrometallurgical method of ONO processing.

$2-4 \%$ to ensure a high degree of reduction of elements from the oxide melt to one stage (without slag removing). If it is necessary to obtain a metal with a low silicon content (less than $1 \% \mathrm{Si}$ ), it is possible to organize a two-stage process with the removing of intermediate slag. 
In the process of silicothermic reduction, acidic slags are formed (with a higher content of $\mathrm{SiO}_{2}$ ), significantly reducing the degree of reduction of the leading elements. To maintain a high degree of reduction of manganese, nickel and minimize the loss of chromium with slag melts, it is necessary to bind formed silicon oxides into thermodynamically strong compounds of dicalcium silicate (2 $\mathrm{CaO} \cdot \mathrm{SiO} 2)$. To solve this problem, it was proposed to use freshly roasted lime as a fluxing material, with a content of $90-95 \%$ $\mathrm{CaO}$. The amount of lime was set with the calculation of maintaining the slag basicity $(\mathrm{CaO} / \mathrm{SiO} 2)$ at the level of 1.9-2.0. As a result, the rate of slag/metal increased to 1.22. The process of reducing nickel and manganese with silicon is exothermic, that leads to a local increase in temperature in the reaction zone to $1600{ }^{\circ} \mathrm{C}$. As a result of the reduction reactions, a slag melt of the following composition was formed, mass. \%: 60 $\mathrm{CaO} ; 31 \mathrm{SiO} 2 ; 7 \mathrm{MgO} ; 2 \mathrm{MnO}$.

Complex ferroalloy contained, mass. \%: $59.0 \mathrm{Ni} ; 16.8 \mathrm{Cr} ; 12.4 \mathrm{Fe} ; 6.5 \mathrm{Mn} ; 2.7 \mathrm{Si} ; 2.6 \mathrm{Co}$. The degree of concentrate components extraction in the alloy is, \%:> $99 \mathrm{Ni}$; > $99 \mathrm{Co}$; $85 \% \mathrm{Mn}$. The resulting complex ferroalloy together with traditional grades of ferrochrome can be used to produce stainless steels.

According to the research results, a hydro-pyrometallurgical method of processing oxidized nickel ores with the production of complex nickel, chromium, manganesecontaining ferroalloys. The flow chart is shown in Figure 4.

\section{Findings}

1. The problem of profitability of processing Russian poor oxidized nickel ores arose in conditions of sharp fluctuations in nickel prices on world markets. As an alternative to the previously existing in Russia, a sulphidation-reducing smelting on a matte, a hydro-pyrometallurgical method has been proposed for the preparation of complex nickel-, chromium, manganese-containing ferroalloys.

2. In the first stage, hydrolytic precipitation (with sodium hydroxide) is considered as a method of processing production solutions from heap leaching of ONO. It is established that at $\mathrm{pH}=5.5, \mathrm{Al}$ is completely removed in the precipitate as hydroxide. After washing from impurities and calcining, the concentrate with 50 wt.\% Al was obtained.

3. In the second stage, at $\mathrm{pH}=9.5$, more than $99 \%$ of nickel and cobalt oxides, as well as $92 \% \mathrm{MnO}$ and $46 \% \mathrm{MgO}$, removed in precipitate. The concentrate obtained after 
washing and calcination at $700^{\circ} \mathrm{C}$ oxide contains, by weight. \%: $67 \mathrm{NiO} ; 3 \mathrm{CoO} ; 20$ $\mathrm{MnO} ; 9 \mathrm{MgO} ; 0,2 \mathrm{~S}$.

4. At the third stage, a pyrometallurgical method for smelting complex ferroalloys of the Fe-Ni-Cr-Mn-Si system using refractory ferrosilicochrome as a reducing agent is proposed for the processing of nickel-containing concentrate.

5. The scheme was developed for the hydro-pyrometallurgical method of processing oxidized nickel ores, including: crushing, heap leaching, hydrolytic precipitation to produce aluminum and nickel-cobalt concentrates, silicothermic smelting to produce complex ferroalloys containing, mass. \%: 59 Ni; 17 Cr; 12 Fe; 6.5 Mn; 2.7 Si; 2.6 Co.

\section{Funding}

This work was supported by the Russian Federation Ministry of Education and Science (state research target for the Institute of Metallurgy, Ural Branch, Russian Academy of Sciences).

\section{References}

[1] (2013). Results of the 7th international conference "Price of stainless steel-2013". Ferrous metals, №. 5, pp.14-16.

[2] Zhuchkov, V.I., Leontyev, L.I., Selivanov, E.N. et al. (2014). Prospects for the production of stainless steel using domestic chrome and nickel ferroalloys in Proceedings of int. scientific-practical conf. "Modern trends in the theory and practice of mining and processing of mineral and technogenic raw materials." Vol. 2. - Ekaterinburg: Ed. Training Center UPI.

[3] Zayakin, O.V., Zhuchkov, V.I. and Leont'ev, L.I. (2018). Electric furnace bath structure during high-chromium ferrochrome production. Metallurgist, vol. 62, pp. 493-500

[4] Mashchenko, V.N., Kniss, V.A., Kobelev, V.A. et al. (2005). Preparation of oxidized nickel ores for smelting. Ekaterinburg: Ural Branch of RAS.

[5] Gavrilov, A.S., Khalezov, B.D., Radushev, A.V. et al. (2017). Percolation leaching of oxidized nickel ores. Butlerov Communications. vol.49, no.2, pp.102-109.

[6] Generalov, V.A., Reznik, I.D. and Kharlakova, T.A. (1995). Methods for producing ferronickel from oxidized nickel ores (part I). Non-ferrous metals, №5, pp.13-17. 
[7] Reznik, I.D., Ermakov, G.P. and Shneerson, Ya.M. (2004). Nickel: in 3 vol. Oxidized nickel ores. Characteristic of ores. Pyrometallurgy and hydrometallurgy of oxidized nickel ores vol. 2. Moscow: LLC "Science and Technology".

[8] Zayakin, O.V. (2002). Development of rational composition and technology of production of nickel-containing ferroalloys from poor oxidized nickel ores. PhD dissertation thesis IMET UB RAS.

[9] Ntuli, F. and Lewis A.E. (2009). Kinetic modeling of nickel powder precipitation by high-pressure hydrogen reduction. Chemical Engineering Science, vol. 64, pp.22022215.

[10] Wang, K., Li, J., McDonald, R.G. et al. (2011). The effect of iron precipitation upon nickel losses from synthetic atmospheric nickel laterite leach solutions: Statistical analysis and modelling. Hydrometallurgy, vol. 109, pp.140-152.

[11] Coto, O., Galizia, F., Hernandez, I. et al. (2008). Cobalt and nickel recoveries from tailings by organic and inorganic bio-acids. Hydrometallurgy, vol. 94, pp.18-22.

[12] Patent RU 2532871, publ. 10 November 2014, Authors: Kalinichenko, I.I., Vaytner, V.V., Molodykh, A.S. and Shubin, V.N.

[13] (2013). Nickel of the Urals. Ways of development, in Collection of round table materials, pp. 17-21, Ekaterinburg: UrFU.

[14] Kolmachikhina, O.B. (2018). Combined technology for processing oxidized nickel ores (by the example of the Serovskoye deposit). PhD dissertation thesis, Ural Federal University named after first President of Russia B.N. Yeltsin.

[15] Ma, B., Yang, W., Yang, B. et al. (2015). Pilot-scale plant study on the innovative nitric acid pressure leaching technology for laterite ores. Hydrometallurgy, № 155. pp.8894.

[16] McDonald, R.G. and Whittington, B.I. (2008). Atmospheric acid leaching of nickel laterites review. Part I. Sulphuric acid technologies. Hydrometallurgy, № 91, pp.35-55

[17] McDonald, R.G. and Whittington, B.I. (2008). Atmospheric acid leaching of nickel laterites review. Part II. Cloride and bio-tecnologies. Hydrometallurgy, № 91, pp.5669.

[18] Barbaroux, R., Mercier, G., Blais, J.F. et al. (2011). A new method for obtaining nickel from the hyperaccumulator plant Alyssum murale. Separation and Purification Technology, vol. 83, pp.57-65.

[19] Zhuchkov, V.I., Zayakin, O.V. and Mal'tsev, Yu.B (2001). Study of melting temperatures and density of ferroalloys containing nickel, Melts, № 1, pp. 7-9. 
[20] Zayakin, O.V., Zhuchkov, V.I. and Lozovaya, E.Yu. (2007). Melting Time of NickelBearing Ferroalloys in Steel. Steel in Translation, vol. 37, No. 5, pp. 416-418.

[21] Gasik, M.I. and Lyakishev, N.P. (1999). Theory and technology of production of ferroalloys. Moscow: Metallurgy. 